\title{
Jurisdictional Discovery Under the Foreign Sovereign Immunities Act
}

\author{
Joseph M. Terry†
}

The United States has long afforded foreign sovereigns immunity from suit in its courts. As early as 1812, in The Schooner Exchange $v$ McFaddon, ${ }^{1}$ Chief Justice Marshall recognized the concept of foreign sovereign immunity, explaining that it arose from the "common interest impelling [sovereign states] to mutual intercourse, and an interchange of good offices with each other."

The importance of foreign sovereign immunity has kept pace with the dramatic growth of international trade and the rise in both the complexity and intensity of relations between nationstates. Today, U.S. corporations and citizens frequently transact with a wide variety of foreign corporate entities: some fully private, some fully state-owned, and many others somewhere in the middle - caught between post-socialist economic privatization and lingering fears of free market competition. ${ }^{3}$ When these transactions go awry the parties often seek to resolve their differences through litigation. The availability of relief in such instances depends largely on whether or not the foreign entity is protected by the law of sovereign immunity. Thus, the law of foreign sovereign immunity plays a critical role for both U.S. citizens conducting business with foreign entities and the foreign entities themselves. Unfortunately, current formulations of U.S. foreign sovereign immunity law provide neither the predictability to deal with modern transnational disputes nor the protections needed to encourage foreign governments to do business with U.S. corporations and to abide by the rulings of U.S. courts.

The American law of foreign sovereign immunity is governed by the Foreign Sovereign Immunities Act ("FSIA"), which codifies both the principle of sovereign immunity and several exceptions to immunity. ${ }^{4}$ In determining the availability of sovereign immu-

† B.A. 1996, Northwestern University; J.D. 1999, The University of Chicago.

11 US (7 Cranch) 116 (1812).

$=$ Id at 137.

3 See The Banking Market, Warsaw Voice 1 (Aug 2, 1998) (discussing EC criticism of large state involvement in Polish banks); Eugene M. Khartukov, Incomplete Privatization Mixes Ownership of Russia's Oil Industry, Oil \& Gas J 36 (Aug 18, 1997).

4 28 USCA §§ 1602-11 (1994 \& Supp 1998). 
nity under the FSIA, courts face two related difficulties. First, the issue of immunity must be determined as a preliminary matter, because federal jurisdiction ${ }^{5}$ over foreign sovereigns exists only when there is a statutory exception to immunity. ${ }^{6}$ Second, because of the ambiguity of the FSIA and the factual complexities of many challenges to FSIA immunity, courts often must conduct significant factfinding prior to determining immunity. Herein lies the paradox. To determine whether the defendant is immune from suit, the court must often permit some discovery. This preliminary discovery, however, may violate the immunity of the foreign sovereign. On the one hand, a strict limitation on discovery may hinder the plaintiff's ability to pursue relief for the tortious and commercial actions of a foreign sovereign. On the other hand, because it is often "impossible to make a decision concerning subject matter jurisdiction without considering the merits" of the case, a permissive discovery rule may result in significant encroachments on foreign states' sovereignty, rendering the protections of the FSIA meaningless and undermining international comity.

American courts have yet to address this dilemma adequately. Typically, courts offer the vague prescription that discovery in these circumstances must be "limited." But courts rarely explain how to conduct or manage limited discovery to determine jurisdiction over foreign sovereigns. Presently, only the Fifth, Second, and D.C. Circuits have articulated standards that extend beyond the simple admonition that any discovery must be limited. ${ }^{9}$ And while these courts have articulated nominally different standards for discovery, each of them fails to afford foreign sovereigns the protections promised by the FSIA.

This Comment analyzes the importance of sovereign immunity, the difficulties faced by a plaintiff litigating against a foreign sovereign, and the difficulties faced by a U.S. court in evalu-

S The FSIA grants jurisdiction to federal and state courts. See Notes of Decision to 28 USCA $\$ 1605$, citing Tennessee Gas Pipeline Co v Continental Gas Co, 814 F Supp 1302, 1308-09 (M D La 1993) (stating that the FSIA does not require that foreign sovereigns be sued in federal courts).

See, for example, 28 USCA \& 1605; Phaneuf v Republic of Indonesia, 106 F3d 302, 305 (9th Cir 1997) ("Subject matter jurisdiction under the FSIA [ ] must be decided before the suit can proceed."); Coleman v Aloolac, Inc, 888 F Supp 1388, 1400 (S D Tex 1995) ("At the outset of every action in a district court against a foreign state, it is of crucial importance for the court to satisfy itself that one of the exceptions to sovereign immunity applies.").

7 First Fidelity Bank NA v Government of Antigua \& Barbuda-Permanent Mission, 877 F2d 189, 196 (2d Cir 1989).

- See, for example, Filus v Lot Polish Airlines, 907 F2d 1328, 1332 (2d Cir 1990).

- See Part III. 
ating challenges to foreign sovereign immunity. Part I describes the FSIA. Part II discusses the competing interests at stake in jurisdictional determinations under the statute. Part III examines the approaches to discovery currently used by courts and identifies some of the deficiencies of these approaches. As an alternative to current formulations, Part IV suggests that courts should permit limited jurisdictional discovery against a foreign sovereign only where the plaintiff (1) produces some evidence of a basis for jurisdiction and (2) demonstrates that discovery is reasonably likely to uncover evidence that will support a finding of jurisdiction beyond a preponderance of the evidence. This approach will allow plaintiffs to pursue discovery where discovery is likely to uncover facts sufficient to uphold jurisdiction, but it will avoid the burdensome "fishing expeditions" that result from more lenient rules.

\section{THE FOREIGN SOVEREIGN IMMUNITIES ACT}

Enacted in 1976, the FSIA provides the "sole and exclusive standards to be used in resolving questions of sovereign immunity raised by foreign states before Federal and State courts in the United States." Although it enacted significant procedural changes, ${ }^{11}$ the FSIA left much of the substantive law of foreign sovereign immunity unchanged, codifying the "restrictive" view of foreign sovereign immunity that has guided U.S. decisionmaking since $1952 .{ }^{12}$

Recognizing the expanding role of foreign states in international commerce, the restrictive view affords immunity only for the public acts of a sovereign and denies it for purely commercial

\footnotetext{
${ }^{10}$ Jurisdiction of Courts in Suits Against Foreign States, HR Rep No 94-1487, 94th Cong, 2d Sess 12 (1976), reprinted in 1976 USCCAN 6604, 6610. See also 28 USCA $\$ 1602$ ("Claims of foreign states to immunity should henceforth be decided by courts of the United States and of the States in conformity with the principles set forth in this chapter.").

"See text accompanying notes 18-26.

12 Prior to 1952, the United States followed the classical or "absolute" view of sovereign immunity, which held that any act of a foreign sovereign must be treated with complete immunity. See, for example, The Schooner Exchange, 11 US (7 Cranch) at 137. The United States abandoned this broad view of immunity in 1952 in the wake of a State Department letter known as the "Tate Letter." See Letter from the Acting Legal Adviser, Department of State, to the Attorney General, Department of Justice, May 19, 1952 ("Tate Letter"), published in 26 Dept State Bull 984, 984 (1952) (discussing the Department of State's reasons for concluding that sovereign immunity "should no longer be granted in certain types of cases"); Gary B. Born, International Civil Litigation in United States Courts 202 (Kluwer Law Intl 3d ed 1996). The U.S. adopted the restrictive view, at least in part, in order to bring its immunity practices in line with those of its trading partners, most of whom had already adopted the restrictive view. Tate Letter, 26 Dept State Bull at 984-85.
} 
acts. ${ }^{13}$ The FSIA codifies this modern theory, qualifying its broad grant of immunity with several exceptions. The FSIA's general immunity provision states that "a foreign state shall be immune from the jurisdiction of the courts of the United States and of the States," ${ }^{14}$ subject to a number of exceptions. ${ }^{15}$ The most significant exception $^{16}$ denies immunity to a foreign state in general where the action is based upon a commercial activity that bares a connection to the United States. ${ }^{17}$

Although the FSIA did little to alter the U.S. law of foreign sovereign immunity conceptually, it introduced two important and related changes to the legal decisionmaking process. First, the FSIA sought to establish firm statutory standards for determinations of sovereign immunity. ${ }^{18}$ Prior to the FSIA, foreign sovereign immunity decisions were made on an ad hoc political basis that offered little predictability to parties hoping to assert or defeat the defense. ${ }^{19}$ Congress expressed concern that "[a] private party who deals with a foreign government entity cannot be certain that his legal dispute with a foreign state will not be decided on the basis of nonlegal considerations through the foreign government's intercession with the Department of State."

${ }^{13}$ See Tate Letter, 26 Dept State Bull at 984-85 (cited in note 12).

" 28 USCA \& 1604.

15 In addition to the "commercial activities exception," id $\$ 1605$ (a)(2), the FSIA withdraws immunity in any case in which the foreign state waives its immunity, id $\$ 1605(a)(1)$; in any case in which the plaintiff alleges the taking of commercial property in violation of international law or the taking of immovable property located in the United States, id \$ 1605(a)(3)-(4); in any case in which "money damages are sought against a foreign state for personal injury or death, or damage to ... property, occurring in the United States and caused by the tortious act or omission of that foreign state," id \$ 1605(a)(5); and in cases alleging personal injury based on a foreign nation's role in torture, extrajudicial killing, aircraft sabotage, or hostage taking where the foreign nation defendant is designated as a state sponsor of terrorism, id $\$ 1605(a)(7)$.

${ }^{16}$ See Republic of Argentina $v$ Weltover, Inc, 504 US 607, 611 (1992) (describing the commercial activity exception as "[ $t$ ]he most significant of the FSIA's exceptions").

${ }^{17} 28$ USCA $\S 1605(a)(2)$ (denying immunity where "the action is based upon a commercial activity carried on in the United States by the foreign state; or upon an act performed in the United States in connection with a commercial activity of the foreign state elsewhere; or upon an act outside the territory of the United States in connection with a commercial activity of the foreign state elsewhere and that act causes a direct effect in the United States").

${ }^{13}$ See 28 USCA $\S \S 1603,1605$ (defining "foreign state" and "commercial activity" and codifying exceptions to foreign sovereign immunity). See also HR Rep No 94-1487 at 1, 6, reprinted in 1976 USCCAN at 6604 (cited in note 10) (explaining that the primary purpose of the act was to provide firm standards for foreign defendants seeking to assert the defense of sovereign immunity).

${ }^{19}$ See HR Rep No 94-1487 at 7, reprinted in 1976 USCCAN at 6605 (cited in note 10) (In enacting the legislation, Congress noted that, "[a]t present, there are no comprehensive provisions in our law available to inform parties when they can have recourse to the courts to assert a legal claim against a foreign state.").

${ }^{20}$ Id at 9 , reprinted in 1976 USCCAN at 6607. 
Second, the FSIA transferred sovereign immunity decisionmaking power from the State Department to the courts. Although nominally vested with the power to determine sovereign immunity prior to $1976,{ }^{21}$ courts made no independent determinations of immunity, deferring instead to the State Department's Office of the Legal Adviser, which held quasi-judicial hearings on immunity. ${ }^{22}$ By transferring the power to make sovereign immunity decisions from the State Department to the judiciary, Congress sought to encourage the development of a consistent and predictable body of law. Prior to the adoption of the FSIA, the State Department was in the "awkward position of a political institution trying to apply a legal standard to litigation already before the courts."23 The result was "considerable uncertainty" for both private parties and foreign states. ${ }^{24}$ Transferring power to the courts substantially depoliticized sovereign immunity decisionmaking. ${ }^{25}$ Congress hoped that by allowing the courts to make independent determinations of immunity, "[t]he Department of State would be freed from pressures from foreign governments ... and from any adverse consequences resulting from an unwillingness of the Department to support that immunity."26 While the FSIA succeeded to a large degree in depoliticizing the process, even judicial determinations of immunity can engender political and economic repercussions, as will be discussed in Parts II and III.

\section{The Challenge IN THE WAKE OF THE FSIA}

Although the FSIA facilitated the development of a more coherent doctrine of immunity, it presented courts with a new challenge: How to resolve often complex and fact-intensive claims of foreign sovereign immunity without impinging on the very interests that immunity seeks to protect. Unable to rely on State

\footnotetext{
${ }^{21}$ In 1943, the Supreme Court held that these recommendations "must be accepted by the courts as a conclusive determination by the political arm of the Government." Ex Parte Republic of Peru, 318 US 578, 589 (1943).

${ }^{22}$ For a description of this process see Daniel G. Partan, The International Law Process 735 (Carolina Academic 1992), citing John A. Boyd, Digest of US Practice in International Law 1977 1018-19 (Dept of State Pub No 8960 (1979)).

${ }^{23} \mathrm{HR}$ Rep No 94-1487 at 8, reprinted in 1976 USCCAN at 6607 (cited in note 10).

${ }^{24}$ Id at 9, reprinted in 1976 USCCAN at 6607; Born, International Civil Litigation at 211 (cited in note 12).

${ }^{25}$ See Partan, The International Law Process at 735 (cited in note 22). For an example of the politicization of immunity determinations, see Rich $v$ Naviera Vacuba, SA, 295 F2d 24 (4th Cir 1961) (per curiam) (accepting the State Department's grant of immunity in a clearly commercial case in order to facilitate the release of a hijacked airplane).

${ }^{26}$ HR Rep No 94-1487 at 7, reprinted in 1976 USCCAN at 6606 (cited in note 10).
} 
Department assessments, courts are now forced to develop their own means of assessing claims of sovereign immunity.

Two related problems complicate this new task. First, the FSIA has transformed the defense of sovereign immunity into a preliminary matter of jurisdiction, effectively forcing resolution of this complex issue at the earliest possible moment in litigation. ${ }^{27}$ Unlike State Department recommendations, judicial determinations of immunity require a preliminary exercise of jurisdictionjurisdiction to determine jurisdiction-that necessarily encroaches, at least minimally, upon sovereign immunity. ${ }^{28}$ Second, the FSIA provides courts little guidance in navigating the complex legal and factual terrain of sovereign immunity. ${ }^{29}$ As a result, courts must often conduct significant factfinding before determining immunity.

\section{A. The Pressure for Early Adjudication}

In general, district courts must determine jurisdictional issues at the outset of litigation..$^{30}$ When the parties contest issues of jurisdiction, courts typically exercise their broad discretion to conduct preliminary jurisdictional discovery. ${ }^{31}$ Occasionally, when unable to determine jurisdiction at the outset, courts will permit litigation to advance as far as the trial stage until sufficient evidence surfaces to resolve jurisdictional disputes. ${ }^{32}$

In the context of foreign sovereign immunity, however, the balance of interests is dramatically realigned. Unlike normal jurisdictional inquiries, inquiries under the FSIA necessarily implicate sovereign interests and often the inquiries themselves may impermissibly intrude upon immunity. Because "sovereign im-

${ }^{27} 28$ USCA § 1604. See also 28 USCA § 1330(a) (1993 \& Supp 1998).

${ }^{28}$ The very exercise of jurisdiction, the hauling into court of the plaintiff, intrudes at least minimally upon the foreign sovereign's right to be free from the entire legal process. As the process intensifies from service of process to discovery to trial and judgment, the intrusion upon the sovereign's interests necessarily increases as well.

20 See Stena Rederi $A B$ v Comision de Contratos del Comite, 923 F2d 380, 385 (5th Cir 1991) ("The operative provisions of the FSIA are deliberately vague-leaving the courts to grasp for creative solutions to sticky questions of sovereign rights.").

${ }_{30}$ See Charles Alan Wright and Arthur R. Miller, 5A Federal Practice and Procedure: Civil $2 d \$ 1350$ at 209-10 (West 1990 \& Supp 1998) (stating that courts should consider a jurisdiction-based motion to dismiss before any other motions, defenses, or objections).

s1 See Oppenheimer Fund, Inc v Sanders, 437 US 340, 351 n 13 (1978) (stating that "where issues arise as to jurisdiction or venue, discovery is available to ascertain the facts bearing on such issues").

${ }^{52}$ See Wright and Miller, 5A Federal Practice $\$ 1350$ at 237-38 n 57 (cited in note 30) (stating that if a jurisdictional issue is interwoven with the merits of the case, the district court may postpone resolution until trial); 63B Am Jur 2d Products Liability $\S 1649$ at 203 (1996) (same). 
munity is immunity from suit, not just from liability, ${ }^{133}$ courts have consistently held that issues of immunity must be resolved at the very outset of litigation. ${ }^{34}$ Consequently, in cases involving foreign sovereigns, courts have been forced to abandon traditional methods of jurisdictional factfinding in favor of more restrictive alternatives. ${ }^{35}$

\section{B. The Complexities of Foreign Sovereign Immunity}

The normal difficulties posed by resolving jurisdictional issues at an early stage in litigation are exacerbated by the complexity and fact-intensive nature of claims of sovereign immunity. Courts and commentators have frequently decried the FSIA for its lack of definitional clarity. ${ }^{36}$ Significantly, the Act fails to define "commercial activities" clearly, despite widespread recognition that " $t]$ ]he determination of whether particular behavior is 'commercial' is perhaps the most important decision a court faces in an FSIA suit. ${ }^{m 7}$ In the past, courts facing challenges to sovereign immunity have struggled over such difficult questions as whether an Iranian bank nationalized in the wake of the Islamic Revolution qualified as a "central bank",38 whether state exploitation of natural resources constituted a commercial or public act; ${ }^{39}$ and whether socialist state entities, such as a Yugoslavian workers' organization ${ }^{40}$ or a Soviet press agency, ${ }^{41}$ should be considered

"Gould, Inc v Pechiney Ugine Kuhlmann, 853 F2d 445, 451 (6th Cir 1988).

${ }^{3}$ See note 6 and accompanying text.

S See Part III.B.

36 See, for example, Gibbons v Udaras na Gaeltachta, 549 F Supp 1094, 1105 (S D NY 1982) (describing the FSIA as a "labyrinth that, owing to the numerous interpretive questions engendered by its bizarre structure and its many deliberately vague provisions, has during its brief lifetime been a financial boon for the private bar but a constant bane of the federal judiciary"); Jeffrey Jacobson, Trying to Fit a Square Peg into a Round Hole: The Foreign Sovereign Immunities Act and Human Rights Violations, 19 Whittier L Rev 757, 777 (noting that the FSIA is "fraught with vague language and confusing intent").

"Texas Trading \& Milling Corp v Federal Republic of Nigeria, 647 F2d 300, 308 (2d Cir 1981).

${ }^{3}$ New England Merchants National Bank $v$ Iran Power Generation and Transmission Co, 502 F Supp 120 (S D NY 1980). For a general discussion of the liability of central banks under the FSIA and attendant proof problems, see Bruce W. Nichols, The Impact of the Foreign Sovereign Immunities Act on the Enforcement of Lenders' Remedies, $1982 \mathrm{U}$ III L Rev 251, 272-83.

${ }^{33}$ Matter of Sedco, Inc, 543 F Supp 561, 564-66 (S D Tex 1982) (finding that drilling an exploratory well was not a commercial activity because "[a] very basic attribute of sovereignty is the control over its mineral resources and short of actually selling these resources on the world market, decisions and conduct concerning them are uniquely governmental in nature").

${ }^{40}$ Edlow International Co v Nuklearna Elektrarna Krsko, 441 F Supp 827, 831-32 (D DC 1977) (noting the difficulties in applying normal standards of government ownership in determining the immunity of socialist entities). 
"agencies or instrumentalities" of a foreign state and therefore immune from suit under the FSIA. Recently, the D.C. Circuit confronted and rejected the novel claim that Iranian state-sponsored terrorism (kidnapping) constituted a commercial act where the kidnapping was expressly designed to force the United States to release millions of dollars in frozen Iranian assets. ${ }^{42}$

Attempts by plaintiffs to prove an FSIA exception through the presence of complex alter-ego relationships ${ }^{43}$ compound the difficulty of resolving questions of sovereign immunity. In most areas of litigation, plaintiffs rely upon alter-ego relationships in order to impute substantive liability; in the FSIA context, however, a demonstration of such a relationship can lead to a determination of immunity that often proves critical to even preliminary findings of jurisdiction. ${ }^{44}$ Furthermore, these relationships are often highly complex and typically require significant factual determinations. For example, in Hester International Corp $v$ Federal Republic of Nigeria, ${ }^{45}$ the Fifth Circuit considered a complex challenge to sovereign immunity based upon Nigeria's alleged alter-ego relationship with a state-created agricultural corporation. In finding no alter-ego relationship, the court probed a series of difficult factual matters: the extent to which the Nigerian government participated in the day-to-day operations of the corporation; the extent to which the corporation secretly represented the government; and whether any Nigerian government employees participated in the corporation's dealings. ${ }^{46}$

Additionally, questions of jurisdiction are often inextricably intertwined with questions of substance, making it nearly impossible to limit discovery to purely jurisdictional questions. ${ }^{47}$ For

"Yessenin-Volpin v Novosti Press Agency, 443 F Supp 849, 852 (S D NY 1978) (noting that the FSIA's definitions of "agency" and "instrumentality" are "ill-suited to concepts which exist in socialist states such as the Soviet Union").

${ }^{42}$ Cicippio $v$ Islamic Republic of Iran, 30 F3d 164 (DC Cir 1994).

43 An alter-ego relationship is one in which "a corporate entity is so extensively controlled by its owner that a relationship of principal and agent is created." First National City Bank v Banco Para el Comercio Exterior de Cuba, 462 US 611, 629 (1983).

4 See, for example, First City, Texas-Houston v Rafidain Bank, 150 F3d 172, 176-77 (2d Cir 1998) (granting discovery where plaintiff alleged alter-ego relationship between defendant and the Iraqi central bank); Dames \& Moore v Emirate of Dubai, 1996 US Dist LEXIS 17030, *9 (N D Cal) (explaining that the court "cannot assert subject matter jurisdiction over the Emirate of Dubai for the acts of the Dubai Municipality absent a factual finding that an agency relationship exists between the two").

45879 F2d 170 (5th Cir 1989).

46 Id at 179-81.

${ }^{47}$ See Jungquist $v$ Sheikh Sultan Bin Khalifa Al Nahyan, 115 F3d 1020, 1027-28 (DC Cir 1997) (noting that courts must engage in substantial factual determinations when faced with a challenge to FSIA immunity); First Fidelity Bank $v$ Government of Antigua \& Barbuda-Permanent Mission, 877 F2d 189, 194-96 (2d Cir 1989) (holding that proof of 
example, First Fidelity Bank $v$ Government of Antigua \& Barbuda-Permanent Mission, ${ }^{48}$ involved a suit against the government of Antigua \& Barbuda for repayment of a bank note provided to an ambassador, allegedly under governmental authority. Antigua argued that although the loan constituted a commercial activity, it was not bound by the ambassador's actions since he acted without state authority in borrowing the money. ${ }^{49}$ If the ambassador acted without authority, Antigua had not engaged in a commercial act and the court could not assert jurisdiction under the FSIA..$^{50}$ Because the question of whether Antigua was bound by the loan constituted a necessary element of jurisdiction as well as support for First Fidelity's substantive claim, any determination of jurisdiction would require inquiry into the merits of the case. ${ }^{51}$

In some instances, to assert jurisdiction under the FSIA, plaintiffs must proffer evidence identical to that needed to prove the substantive claim. For example, in Greenpeace, Inc $v$ France, ${ }^{52}$ the plaintiffs' attempts to prove a noncommercial tort exception to immunity ${ }^{53}$ depended entirely on their ability to prove their substantive claim-that they were victims of the noncommercial tort. Proof of a substantive claim served as a prerequisite for jurisdiction.

\section{Competing Interests}

Courts must design discovery rules that will not only overcome these significant factfinding difficulties but will also strike a tenable balance between the plaintiff's need for discovery and the foreign sovereign's need for protection from litigation. On the one hand, excessively stringent discovery rules will deprive plaintiffs of opportunities to redress the wrongs of foreign state actors, effectively eliminating the exceptions to foreign sovereign immu-

apparent authority was essential to both a finding of jurisdiction and a decision on the merits); Corporacion Venezolana de Fomento v Vintero Sales Corp, 629 F2d 786, 790-91 n 4 (2d Cir 1980) (finding that "[i]n many cases a resolution of the substantive immunity law issues will be required in order to reach a decision on subject matter jurisdiction"); Upton $v$ Empire of Iran, 459 F Supp 264, 265 (D DC 1978) (noting that the FSIA “creates an identity of substance and procedure").

877 F2d 189 (2d Cir 1989).

10 Id at 191.

so Id at 195-96.

s1 The court granted discovery to resolve jurisdictional issues even though they were "interwoven with the merits." Id at 196.

s2 946 F Supp 773 (C D Cal 1996) (plaintiff environmentalists alleged that Air France employees "physically struck" and unlawfully detained them during layover in the United States).

\% 28 USCA $\$ 1605(\mathrm{a})(5)$. 
nity and frustrating the FSIA's policy of holding foreign sovereigns accountable for certain activities. On the other hand, liberal discovery rules may eviscerate foreign sovereigns' immunity from suit, undermining international comity ${ }^{54}$ and the legitimacy of U.S. courts in the international arena.

1. The defendant's need for protection from discovery.

American courts have traditionally treated the concept of sovereign immunity as "a matter of grace and comity" - a recognition of the common interests of nations-rather than as a constitutional command. ${ }^{56}$ As the international community began to abandon the classical doctrine of absolute immunity in favor of a more restrictive doctrine of foreign sovereign immunity, the United States followed suit. ${ }^{57}$ However, with the enactment of the FSIA and the concomitant shift in decisionmaking authority from the executive branch to the judiciary ${ }^{58}$ foreign states became subject to the jurisdiction of U.S. courts and broad pretrial discovery practices. In struggling to define appropriate limits for jurisdictional discovery against foreign sovereigns, courts have noted two primary concerns. First, because even jurisdictional discovery is likely to be broad and highly intrusive when conducted against foreign sovereigns, the FSIA must provide foreign states with "not merely a defense to liability, but immunity from the burdens of litigation as well." ${ }^{159}$ Second, overly permissive discovery rules are likely to engender international hostility and may undermine both "judicial comity among nations" ${ }^{\text {"60 }}$ and international confidence in the U.S. judicial system.

a) Sovereign immunity provides complete protection from litigation. The law of foreign sovereign immunity is designed not only to protect foreign government agencies and officers from adverse judgments but also "to promote the functioning of all governments by protecting a state from the burden of defending law suits abroad which are based on its public acts." ${ }^{\text {"61 }}$ Indeed, courts

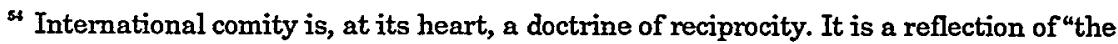
systemic value of reciprocal tolerance and goodwill." Société Nationale Industrielle Aérospatiale v United States District Court for the Southern District of Iowa, 482 US 522, 555 (1987) (Blackmun concurring in part and dissenting in part).

${ }^{65}$ Verlinden BV v Central Bank of Nigeria, 461 US 480, 486 (1983).

se Id.

${ }^{57}$ See note 12 and accompanying text.

${ }^{s s}$ See text accompanying notes 21-26.

${ }^{59}$ Gabay v Mostazafan Foundation of Iran, 151 FRD 250, 256 (S D NY 1993).

${ }^{\infty}$ Arriba, Ltd v Petroleos Mexicanos, 962 F2d 528, 537 (5th Cir 1992).

${ }^{21}$ Foreign Sovereign Immunities Act of 1975, Hearings on HR 11315 before the House Subcommittee on Administrative Law and Governmental Relations, 94th Cong, 2d Sess 27
} 
frequently analogize FSIA immunity to the "qualified immunity"\$2 that largely shields U.S. government officials from discovery and liability in cases alleging civil damages resulting from their good faith performance of discretionary duties. ${ }^{63}$ To be meaningful, the law of foreign sovereign immunity must protect foreign sovereigns, as qualified immunity protects U.S. officials, from all aspects of the litigation process, including the "broad-ranging discovery' that can be 'peculiarly disruptive of effective government." ${ }^{\prime 64}$ Moreover, courts have long recognized that the doctrine of foreign sovereign immunity is rooted in a respect for the dignity of sovereign states and the judgment that the United States should not diminish this dignity by forcing the foreign sovereign to appear before a U.S. court. ${ }^{65}$ Thus, even an initial exercise of jurisdiction undermines one of the principles behind sovereign immunity.

Furthermore, the Supreme Court has warned lower courts to "exercise special vigilance" to protect all foreign litigants from the burdens of discovery. ${ }^{66}$ The Court has noted that "the additional cost of transportation of documents or witnesses to or from foreign locations may increase the danger that discovery may be sought for the improper purpose of motivating settlement, rather than finding relevant and probative evidence." 67

Because issues of jurisdiction and substance are often tightly interwoven in cases against foreign sovereigns, ${ }^{68}$ any jurisdictional discovery is likely to be both wide-ranging and intrusive. Determinations of FSIA jurisdiction often require discovery on foreign soil and inquiry into the domestic affairs of foreign nations, probing into sensitive political and economic issues. ${ }^{69}$

(1976) (statement of Monroe Leigh, State Dept Legal Advisor).

" See, for example, Segni v Commercial Office of Spain, 816 F2d 344, 347 (7th Cir 1987); Arriba, 962 F2d at 534.

s Qualified immunity protects government officials only "insofar as their conduct does not violate clearly established statutory or constitutional rights of which a reasonable person would have known." Crawford-El v Britton, 523 US 574, 118 S Ct 1584, 1592 (1998). For a thorough discussion of qualified immunity, see Mary Massaron Ross, ed, Sword \& Shield Revisited: A Practical Approach to Section 1983 (ABA 1998).

"Anderson v Creighton, 483 US 635, 646 n 6 (1987) (discussing qualified immunity), quoting Harlow v Fitzgerald, 457 US 800, 817 (1982).

${ }^{\infty}$ See The Schooner Exchange, 11 US (7 Cranch) at 136.

"société Nationale Industrielle Aérospatiale, 482 US at 546.

"Id.

* See Part II.B.

* See for example, In re Papandreou, 139 F3d 247, 252 (DC Cir 1998) (State Department intervened on behalf of Greece due to "sensitive diplomatic considerations involved."); Arriba, 962 F2d at 536 n 15 (Defendant requested many documents pertaining to the relationship between the Mexican national oil supplier and private corporations, including documents referring to internal investigations of "any alleged misconduct, in- 
Challenges to sovereign immunity are often predicated upon proof of alter-ego relationships and, as a result, discovery requests will often touch on sensitive matters of political comuption, ${ }^{70}$ relationships between central governments and industrial organizations, ${ }^{71}$ and relationships between foreign governments and terrorist organizations. ${ }^{72}$ Indeed, as privatization flourishes and American corporations begin to bring suits against the newly privatized corporations of China and the former Soviet Union, discovery requests will increasingly encroach upon sensitive issues of industrial relations, corruption, and political influence. ${ }^{73}$

b) Comity among nations. While the United States' treatment of foreign sovereign immunity bears a striking resemblance to that of the international community, American discovery practices stand alone. As the Restatement (Third) of Foreign Relations explains, "No aspect of the extension of the American legal system beyond the territorial frontier of the United States has given rise to so much friction as the requests for documents in investigation and litigation in the United States." ${ }^{\text {" }}$

Even greater friction can be expected when American plaintiffs demand that foreign sovereigns produce governmental mate-

cluding bribery, extortion, ultra vires acts, tax evasion, embezzlement and any other possible violations of U.S. or Mexican law."); Crist $v$ Republic of Turkey, 995 F Supp 5, 6-7 (D DC 1998) (Plaintiffs requested discovery regarding Turkish treatment of Greek nationals living on Cyprus.).

${ }^{70}$ See Phaneuf $v$ Republic of Indonesia, 106 F3d 302, 307 (9th Cir 1997) (examining the authority of an Indonesian defense agency to authorize promissory notes); Arriba, 962 F2d at 530-32, 534, 536 n 15 (alleging corrupt relationship between Mexican national oil company and private oil corporations).

${ }^{71}$ See Rafidain Bank, $150 \mathrm{~F} 3 \mathrm{~d}$ at 174 (alleging alter-ego relationship between Iraqi central bank and purportedly private Iraqi bank); Arriba, 962 F2d at 530-32.

${ }^{72}$ See Cicippio, 30 F3d at 168 (alleging that the Islamic Republic of Iran was responsible for the kidnapping of American hostages and that such action constituted a commercial activity since hostages were held in order to persuade the U.S. to release frozen Iranian assets).

${ }^{73}$ See, for example, Reinsurance Co of America v Administratia Asigurarilor de Stat, 902 F2d 1275, 1278-81 (7th Cir 1990) (seeking discovery of information made newly available after the fall of Romania's communist regime); Richmark Corp v Timber Falling Consultants, 959 F2d 1468, 1474-79 (9th Cir 1992) (sanctioning corporation of the People's Republic of China for failing to respond to discovery requests aimed at ascertaining the corporation's worldwide assets on the grounds of state secrecy).

"Restatement (Third) of the Foreign Relations Law of the United States § 442, Rep Note 1 at 354 (ALI 1987). See also Environmental Tectonics v W.S. Kirkpatrick, Inc, 847 F2d 1052, 1062 n 11 (3d Cir 1988) ("Foreign governments have often expressed their dissatisfaction with the wide discovery authorized under the Federal Rules, finding it intrusive and overbroad when compared to the European version of the fact-finding process."). As one scholar noted, "Foreign governments assert their sovereign right to control documents, witnesses, and other evidence located within their territory and characterize unilateral U.S. efforts to compel the production of such evidence in U.S. proceedings as infringements on their sovereign prerogatives and territorial integrity." Born, International Civil Litigation at 850 (cited in note 12). 
rials prior to even a preliminary determination of jurisdiction. Permissive discovery rules in the context of foreign sovereign immunity are likely not only to exacerbate the international trend toward blocking statutes ${ }^{75}$ but may also "undermine the State Department's continuing efforts to encourage . . . foreign sovereigns generally [ ] to resolve disputes within the United States' legal framework." "76 Furthermore, by failing to give full respect to international comity, particularly where sensitive economic and political issues are concerned, U.S. courts risk harming America's diplomatic relations with foreign states. ${ }^{77}$ Finally, permissive discovery rules may encourage foreign states to modify their own immunity laws in a manner hostile to U.S. interests. ${ }^{78}$ As Justice Blackmun explained in a related context, "The United States is increasingly concerned ... with protecting sensitive technology for both economic and military reasons. It may not serve the country's long-term interest to establish precedents that could allow foreign courts to compel production of the records of American corporations." ${ }^{\text {m9 }}$

${ }^{73}$ In the last twenty years, hostility towards U.S. discovery practices has led a number of foreign states to erect "blocking statutes" designed to stymie the reach of American judicial discovery orders. These statutes typically prohibit citizens from complying with U.S. discovery orders demanding the production of evidence located within a foreign state's territory. See, for example, French Penal Code Law No 80-538, Arts la \& 2, in Bulletin Législatif 285 (Dalloz 1980), translated in Born, International Civil Litigation at 853-54 (cited in note 12) ("[I]t is prohibited for any person ... to request, to investigate or to disclose . . economic, commercial, industrial, financial or technical matters leading to the constitution of evidence with a view to foreign judicial or administrative proceedings." ${ }^{\prime \prime}$. Approximately fifteen foreign nations have enacted similar statutes. See Born, International Civil Litigation at 850-52.

${ }^{76}$ Foremost-McKesson, Inc v Islamic Republic of Iran, 905 F2d 438, 445 (DC Gir 1990), quoting Practical Concepts, Inc v Republic of Bolivia, 811 F2d 1543, 1551 n 19 (DC Cir 1987).

"See Arriba, 962 F2d at 537 ("Judicial comity among nations . . has become increasingly important to today's global economy. Flouting comity, Arriba's JFK-like charges against the defendants, if pursued in American courts, could seriously impede our relations with Mexico.") (footnote omitted). See also Papandreou, 139 F3d at 252 (State Department intervened as amicus for Greece, noting the "sensitive diplomatic considerations" involved in the case.).

${ }^{78}$ For example, the State Department opposed the 1996 amendments to the FSIA, which retracted immunity in cases of torture and extrajudicial killing. As one Representative argued, "The risk to American assets abroad would be significant should other countries respond ... by enacting further exceptions to their foreign sovereign immunity laws which are broader in scope that [sic] is [this amendment]. Foreign Sovereign Immunities Amendments, HR Rep No 103-702, 103d Cong, 2d Sess 12 (1994) (dissenting views of Rep McCollum).

73 Société Nationale Industrielle Aérospatiale, 482 US at 552 n 3 (Blackmun concurring in part and dissenting in part) (discussing U.S. discovery practice in the context of the Hague Convention). 


\section{The plaintiff's need for discovery.}

Despite foreign sovereigns' legitimate interests in avoiding intrusive and burdensome discovery, plaintiffs' interests in conducting adequate discovery remain strong. ${ }^{80}$ Indeed, two factors converge to make discovery particularly important in the context of foreign sovereign immunity determinations: the location of jurisdictional evidence and the high evidentiary burden that the FSIA places on the plaintiff to prove jurisdiction.

a) Location of the evidence. Plaintiffs are often unable to prove an exception to the FSIA without significant discovery. ${ }^{8 I}$ Proof of an exception to immunity is highly fact dependent ${ }^{82}$ and may require evidence that is in the exclusive possession of defendants. ${ }^{83}$

Determinations of foreign sovereign immunity frequently entail inquiry into the inner workings and political structures of foreign states. ${ }^{84}$ For example, courts have required plaintiffs to demonstrate that agents of the Indonesian National Defense Security Council were authorized to issue promissory notes; ${ }^{85}$ that the commercial activities of an Iranian charitable foundation located in New York could be attributed to the Iranian government; ${ }^{86}$ and that agents of the Soviet Union participated in the service and maintenance of Soviet aircraft used by the Polish national airline. ${ }^{87}$ Absent discovery, plaintiffs are unlikely to have access to such information, since often it is not available in the public sphere. Without adequate discovery, courts will be forced to rely upon foreign states' categorical denials of liability (and as-

${ }^{80}$ See Millicom International Cellular, SA v Republic of Costa Rica, 1997 US Dist IEXIS 12622, *4 (D DC) ("[P]laintiffs do, in fact, have a right to conduct preliminary discovery in such cases if it is directed towards resolving the issue of whether FSIA immunity applies.").

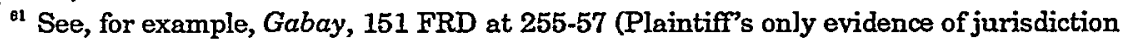
was inadmissible as hearsay, but it served to demonstrate that discovery would uncover admissible evidence of jurisdiction.); Millicom, 1997 US Dist LEXIS 12622 at *23 (Plaintiffs argued that "only discovery can determine the full extent of the defendants' operations in, and contacts with, the United States.").

See Part II.B.

*3 See generally Note, The Use of Discovery to Obtain Jurisdictional Facts, $59 \mathrm{Va}$ L Rev 533, 541 (1973) ("Frequently the facts necessary to resolve the jurisdiction issue are solely within the defendant's knowledge.").

64 This is particularly likely where the plaintiff's jurisdictional theory relies on an alter-ego relationship between a foreign state and a corporation. See text accompanying notes $43-46$.

${ }^{85}$ Phaneuf, 106 F3d at 307.

${ }^{80}$ Gabay, 151 FRD at 257-58.

${ }^{87}$ Filus $v$ Lot Polish Airlines, 907 F2d 1328, 1333 (2d Cir 1990) (granting plaintiff's requests for interrogatories as to who designed the engines of the Soviet plane, who manufactured the plane, who assembled the plane, who serviced the plane, etc.). 
sertions of immunity), leaving plaintiffs without recourse. Because strict limitations on discovery will force plaintiffs to rely exclusively on public information, discovery limitations may benefit politically repressive states that strictly control access to such information.

b) Plaintiff's evidentiary burden. Although the text of the FSIA is silent as to burdens of proof of immunity, both the legislative history and subsequent judicial interpretation of the Act have placed a high evidentiary burden on plaintiffs. The House Report explained that, although the foreign sovereign must produce prima facie evidence of immunity, "the burden of going forward would shift to the plaintiff to produce evidence establishing that the foreign state is not entitled to immunity. ${ }^{288}$ Courts have further heightened the evidentiary burden by requiring plaintiffs to overcome a presumption that the instrumentalities and agencies of a foreign sovereign are independent actors. ${ }^{89}$ Because exceptions to sovereign immunity frequently turn on the strength of the relationship between a foreign state and its instrumentalities, ${ }^{90}$ this presumption presents a substantial hurdle in the path of any plaintiff seeking to overcome a defense of foreign sovereign immunity. ${ }^{91}$

\section{THE COURTS' ENIGMATIC ANSWER-LIMITED DISCOVERY}

In balancing these competing interests, courts uniformly recognize that discovery must be limited to the facts necessary to determine immunity. ${ }^{92}$ Despite the broad acceptance of limited dis-

* HR Rep No 94-1487 at 17, reprinted in 1976 USCCAN at 6616 (cited in note 10).

* See First National City Bank, 462 US at 629 (explaining that this presumption of independence can be overcome by a showing that the "entity is so extensively controlled by its owner that a relationship of principal and agent is created"). See also ForemostMcKesson, 905 F2d at 446 ("The presumption of the juridicial separateness of entities also applies to jurisdictional issues."); Hester, 879 F2d at 176 (explaining that plaintiff "bears the burden of proving the agency relationship" at trial).

${ }^{30}$ See Foremost-McKesson, 905 F2d at $446-47$ (remanding to the district court for factual determination of sufficient control by the defendant over its instrumentality "to create a relationship of principal to agent" ${ }^{\prime \prime}$. See also Gilson $v$ Republic of Ireland, 682 F2d 1022, 1026 n 16, 1029-30 (DC Cir 1982) (finding that jurisdiction may hinge on "whether the required agency existed").

" See, for example, Foremost-McKesson, 905 F2d at 447 (stating that "absent an agency relationship, the court lacks subject matter jurisdiction over the foreign state for the acts of its instrumentality"); Hester, 879 F2d at 176-77 (attempting to establish jurisdiction, plaintiff sought to prove exception to the FSIA on the basis of an alter-ego relationship between Nigeria and the National Grain Production Company).

"See, for example, First City, Texas-Houston v Rafidain Bank, 150 F3d 172, 176-77 (2d Cir 1998); Voest-Alpine Trading USA Corp v Bank of China, 142 F3d 887, 896 n 13 (5th Cir 1998); In re Papandreou, 139 F3d 247, 252-54 (DC Cir 1998); Gould, Inc v Pechiney Ugine Kuhlmann, 853 F2d 445, 451 (6th Cir 1988); Greenpeace, 946 F Supp at 
covery, the concept remains largely undeveloped. Few courts have adopted a systematic approach to limiting jurisdictional discovery in FSIA cases. Those courts that have dealt specifically with the question have created a variety of requirements for plaintiffs seeking discovery. Every court to address the issue explicitly has advocated some form of heightened jurisdictional pleading. This Comment will analyze both (1) traditional rules of jurisdictional discovery and (2) the current forms of heightened pleading in the FSIA context. This Comment argues that these approaches are unpredictable and inadequately protect the immunity of foreign sovereign entities. ${ }^{93}$

\section{A. The Traditional Permissive Approach}

In most contexts, district courts enjoy broad discretion to determine the scope of their jurisdiction. When jurisdiction is challenged, traditional practices afford a district court vast discretion to define the contours of jurisdictional discovery. ${ }^{94}$ This discretion extends to both the initial decision to permit jurisdictional discovery and to later decisions regarding the scope of that discovery. ${ }^{95}$

Accordingly, outside the context of FSIA claims, courts usually will permit jurisdictional discovery whenever "pertinent facts bearing on the questions of jurisdiction are controverted, or [ ] a more satisfactory showing of the facts is necessary." In contrast, courts typically deny discovery where plaintiffs have had ample opportunity to conduct discovery yet failed to do $\mathrm{so}^{97}$ or "when it is clear that further discovery would not demonstrate facts sufficient to constitute a basis for jurisdiction. ${ }^{\text {1988 }}$

789.

9s These two categories, while analytically useful, do not reflect any clear cut circuit split. It is perhaps a measure of the underdevelopment of this area of law that courts have neither identified nor addressed the differences between the analytical approaches.

"See Wells Fargo \& Co v Wells Fargo Express Co, 556 F2d 406, 430-31 n 24 (9th Cir 1977) (describing jurisdictional discovery as "generally left to the discretion of the trial court"s).

${ }^{95}$ See Naartex Consulting Corp v Watt, 722 F2d 779, 788 (DC Cir 1983) ("[A] district court has broad discretion in its resolution of discovery problems that arise in cases pending before it."), quoting In re Multi-Piece Rim Products Liability Litigation, 653 F2d 671, 679 (DC Cir 1981); Wells Fargo, 556 F2d at 430-31 n 24 ("An appellate court will not interfere with the trial court's refusal to grant [jurisdictional] discovery except upon the clearest showing that the dismissal resulted in actual and substantial prejudice to the litigant.").

${ }^{9}$ Kilpatrick v Texas \& Pacific Railway, 72 F Supp 635, 638 (S D NY 1947), revd on other grounds, 166 F2d 788 (2d Cir 1948).

${ }^{97}$ Naartex, $722 \mathrm{~F} 2 \mathrm{~d}$ at $788 \mathrm{n} 15$.

${ }^{98}$ Wells Fargo, 556 F2d at $430-31$ n 24. 
In the context of FSIA claims, however, the court must evaluate not only the importance of discovery to the plaintiff but also the unique burdens that discovery may place on foreign sovereigns. ${ }^{99}$ While no court has explicitly embraced the use of traditional jurisdictional discovery practices in determining FSIA claims, ${ }^{100}$ an understanding of the traditional approach and its shortcomings is essential to understanding the insufficiency of the current alternative approaches to jurisdictional discovery under the FSIA.

Traditional permissive approaches to jurisdictional discovery cannot adequately serve the goals of the FSIA. First, because foreign sovereign immunity guarantees "immunity from suit and not just from judgement," trate the significance and benefit of entitlement to immunity from suit." Rules that permit discovery whenever "pertinent facts bearing on the question of jurisdiction are in dispute"103 are likely to subject states deserving of FSIA protection to burdensome discovery.

Second, traditional approaches to jurisdictional discovery are inconsistent with the discovery rules governing qualified immunity determinations for public servants. Congress intended to provide foreign sovereigns with immunity similar to that enjoyed by U.S. governmental actors. ${ }^{104}$ Failure to limit discovery against

" See Part II.C.I.

${ }^{100}$ In a number of cases, however, courts in the Ninth Circuit have used traditional approaches to jurisdictional discovery in determining claims against foreign sovereigns. See America West Airlines, Inc v GPA Group, Ltd, 877 F2d 793 (9th Cir 1989); Greenpeace, 946 F Supp 773. In each of these cases the courts espoused traditional notions of jurisdictional discovery. Nevertheless, in each case the Ninth Circuit refused to allow discovery, albeit for reasons consistent with even the traditional permissive approach. See America West, 877 F2d at 801 (refusing to permit discovery where: plaintiffs discovery request were "largely unrelated" to the question of jurisdiction; the defendants had already answered plaintiff's jurisdictional interrogatories; and plaintiff had failed to request additional discovery until confronted with a motion to dismiss); Greenpeace, 946 F Supp at 789 (refusing to permit discovery where plaintiff could not show "any possibility that they might demonstrate the requisite jurisdictional facts if afforded the opportunity for additional discovery"). In neither case did the court recognize the need to provide foreign sovereigns with special protections. The Ninth Circuit's recent decision in Phaneuf $v$ Republic of Indonesia, 106 F3d 302 (9th Cir 1997), however, suggests that the court may be leaning toward adopting a heightened standard for discovery against foreign sovereigns. Id at 305-06 (noting that "[i]mmunity under the FSIA is not only immunity from liability, but immunity from suit," but failing to explicate any heightened pleading standard in cases arising under the Act). Thus, it remains unclear whether the Ninth Circuit continues to adhere to traditional discovery practices even in the face of foreign sovereign immunity.

${ }^{101}$ Segni v Commercial Office of Spain, 816 F2d 344, 346 (7th Cir 1987).

${ }^{102}$ Gould, 853 F2d at 451 .

${ }^{105}$ America West, $877 \mathrm{~F} 2 \mathrm{~d}$ at 801.

${ }^{104}$ See Segni, 816 F2d at 347 (discussing congressional intent to create protections similar to the qualified immunity of U.S. public officials), citing hearings on HR 11315 
foreign sovereigns is inconsistent with this congressional intent. In the qualified immunity context, courts have invariably refused to grant plaintiffs discovery against U.S. government officers absent a substantial showing that such discovery was likely to produce evidence defeating qualified immunity. ${ }^{105}$ District courts may insist that "the plaintiff 'put forward specific, nonconclusory factual allegations' that establish improper motive" before permitting discovery in the qualified immunity context. ${ }^{106}$

Similar protection from discovery should be afforded to foreign sovereigns for three reasons. First, the Supreme Court has explicitly instructed lower courts to exercise special vigilance in protecting foreign litigants from the undue burdens of international discovery and in respecting "any sovereign interest expressed by a foreign state." 107 Second, in enacting the FSIA, Congress clearly expressed its intent to provide foreign sovereigns with a level of protection commensurate with that enjoyed by federal and state government officials. ${ }^{108}$ Third, although the legislative history of the FSIA illuminates Congress's desire to protect the litigation interests of U.S. plaintiffs suing foreign sovereigns, ${ }^{109}$ the plaintiffs' interests in the FSIA context pale in comparison to the interests at stake in federal civil rights suits-the vindication of the plaintiffs' constitutional and statutory rights. ${ }^{110}$

(cited in note 61); HR Rep No 94-1487 (cited in note 10); S Rep No 94-1310, 94th Cong, 2d Sess (1976).

${ }^{100}$ See, for example, Blue $v$ Koren, 72 F3d 1075, 1084 (2d Cir 1995); Schultea $v$ Wood, 47 F3d 1427, 1434 (5th Cir 1995) (en banc); Veney v Hogan, 70 F3d 917, 922 (6th Cir 1995); Edgington v Missouri Department of Corrections, 52 F3d 777, 779-80 (8th Cir 1995); Walter $v$ Morton, 33 F3d 1240, 1243 (10th Cir 1994); Oladeinde $v$ City of Birmingham, 963 F2d 1481, 1485 (11th Cir 1992); Gooden v Howard County, Maryland, 954 F2d 960, 969-70 (4th Cir 1992); Branch v Tunnell, 937 F2d 1382, 1387-88 (9th Cir 1991); Elliott v Thomas, 937 F2d 338, 344-45 (7th Cir 1991); Colburn v Upper Darby Township, 838 F2d 663, 666 (3d Cir 1988).

${ }^{108}$ Crawford-El v Britton, 523 US 574, $118 \mathrm{~S} \mathrm{Ct} 1584,1596-97$ (1998), quoting Siegert $v$ Gilley, 500 US 226, 236 (1991) (Kennedy concurring).

${ }^{10}$ See Société Nationale Industrielle Aérospatiale v United States District Court for the Southern District of Iowa, 482 US 522, 546 (1987) ("American courts, in supervising pretrial proceedings, should exercise special vigilance to protect foreign litigants from the danger that unnecessary, or unduly burdensome, discovery may place them in a disadvantageous position.").

${ }^{108}$ See Segni, 816 F2d at 347 (discussing congressional intent to create protections similar to the qualified immunity of U.S. public officials).

${ }^{109}$ See HR Rep No 94-1487 at 8, reprinted in 1976 USCCAN at 6606-07 (cited in note 10) (noting that the Act makes it easier for U.S. citizens to serve process upon, obtain jurisdiction against, and obtain final relief against foreign states). Compare with id at 45, reprinted in 1976 USCCAN at 6634 (purposes of the FSIA are to "facilitate and depoliticize litigation against foreign states and to minimize irritations in foreign relations arising out of such litigation").

${ }^{110} \mathrm{See} C$ Crawford-El, $118 \mathrm{~S} \mathrm{Ct}$ at 1593 (noting that qualified immunity of government officers restricts private damage actions that are often "the only realistic avenue for vindi- 
Finally, the application of traditional jurisdictional discovery rules in the foreign sovereign immunity context conflicts with the notion of intermational comity that underlies foreign sovereign immunity. ${ }^{111} \mathrm{By}$ failing to consider either the unique burden that discovery places on foreign defendants, or the risks of abuse and intrusion that attend any judicial inquiry into the affairs of a foreign state, the traditional approach ignores the principles of comity and increases the danger that discovery will heighten the already intense international animosity towards U.S. discovery practice. ${ }^{12}$ Such animosity can only hinder American efforts to encourage foreign sovereigns to "resolve disputes within the United States' legal framework"113 and to permit U.S. corporations to enter the previously closed markets of Eastern Europe and Asia. ${ }^{114}$

\section{B. Heightened Pleading}

In contrast to the discretion permitted by the traditional view, several courts have attempted to define more narrowly the appropriate grounds for initiating jurisdictional discovery against a defendant who has asserted a defense of foreign sovereign immunity. ${ }^{115}$ These courts typically stress the significance of foreign sovereign immunity and the unique burdens facing a foreign sovereign defendant. Beyond these general principles, however, courts have offered little uniformity in their discovery standards.

The most widely enunciated standard provides that discovery must be ordered "circumspectly and only to verify allegations of

cation of constitutional guarantees"), quoting Harlow v Fitzgerald, 457 US 800,814 (1982).

II'See The Schooner Exchange, 11 US (7 Cranch) at 137 (explaining traditional justification for foreign sovereign immunity).

${ }^{112}$ See Part II.C.1.b.

${ }^{113}$ Foremost-McKesson, Inc v Islamic Republic of Iran, 905 F2d 438, 445 (DC Cir 1990), quoting Practical Concepts, Inc v Republic of Bolivia, 811 F2d 1543, 1551 n 19 (DC Cir 1987).

${ }^{\text {"I }}$ Although permissive discovery rules may decrease the risks that U.S. corporations face when dealing with foreign governments and their agencies and instrumentalities, such discovery will also decrease the willingness of foreign governments to deal with U.S. corporations for fear of exposing themselves to U.S. discovery procedures. Permissive discovery rules have been criticized on a similar basis in the context of qualified immunity. As Judge Silberman explained in Crawford-El $v$ Britton, "It is perhaps one of the simplest axioms of law and economics that overdeterrence as well as undeterrence yields inefficient results." 93 F3d 813, 834 (DC Cir 1996) (Silberman concurring).

${ }^{115}$ See, for example, Arriba, Ltd v Petroleos Mexicanos, 962 F2d 528, 534 (5th Cir 1992); Rafidain Bank, 150 F3d at 176; Millicom International Cellular, SA v Republic of Costa Rica, 1997 US Dist LEXIS 12622, *4 (D DC); Crist $v$ Republic of Turkey, 995 F Supp 5, 12 (D DC 1998); Gabay v Mostazafan Foundation of Iran, 151 FRD 250, 256-57 (S D NY 1993). 
specific facts crucial to an immunity determination."116 This standard was initially advanced by the Fifth Circuit in Arriba, Ltd $v$ Petroleos Mexicanos, ${ }^{117}$ which reversed a district court decision permitting limited jurisdictional discovery where the plaintiff had alleged jurisdiction under the FSIA's commercial activities exception. ${ }^{118}$ The Court of Appeals criticized the district court's reliance on traditional jurisdictional discovery procedures ${ }^{119}$ and noted the "tension between permitting discovery to substantiate exceptions to statutory foreign sovereign immunity and protecting a sovereign's or sovereign agency's legitimate claim to immunity from discovery." flicts that frequently arise in connection with domestic government officials' claims of qualified immunity, the Fifth Circuit demanded that district courts more narrowly prescribe jurisdictional discovery against foreign sovereigns. ${ }^{121}$ The court held that "[a] necessary prerequisite to an order for limited discovery is a district court's clear understanding of the plaintiff's claims against a sovereign entity,"122 and further explained that "discovery may be used to confirm specific facts that have been pleaded as a basis for enforcing the commercial activities exception, but it cannot supplant the pleader's duty to state those facts at the outset of the case." 123

In Gabay $v$ Mostazafan Foundation of Iran, ${ }^{124}$ the District Court for the Southem District of New York relied on the Fifth Circuit's approach, finding that Arriba's threshold requirement had been met where the plaintiff presented "an array of documents that, taken together," suggested that "admissible evidence might well be obtained if discovery were permitted." 125 Furthermore, the court employed a balancing test, noting that because the plaintiff's discovery requests presented little "risk of significant encroachment on a foreign instrumentality's immunity from suit," the equities weighed in favor of discovery. ${ }^{126}$

${ }^{116}$ Arriba, 962 F2d at 534.

${ }^{117} 962$ F2d 528 (5th Cir 1992).

${ }^{118}$ Id at 534.

${ }^{119}$ Id (criticizing the district court for "drawing an analogy to the usual procedure for resolving contested jurisdictional issues").

${ }^{120} \mathrm{Id}$.

${ }^{221}$ Id ("The potential conflict is not unlike that attendant to claims that challenge domestic government officials' qualified immunity from suit.").

${ }^{122}$ Id.

${ }^{125}$ Id at $537 \mathrm{n} 17$.

${ }^{124} 151$ FRD 250 (S D NY 1993).

${ }^{125}$ Id at 256-57.

${ }^{126}$ Id at 257. 
Since Arriba, courts have articulated a variety of different standards for determining when to permit jurisdictional discovery in the FSIA context. The Second Circuit, apparently adopting the Arriba standard, interpreted the decision as requiring an explicit balancing test between the plaintiff's need for discovery to "substantiate exceptions to statutory foreign sovereign immunity" and the need to protect a foreign sovereign's "legitimate claim to immunity from discovery." ${ }^{\prime 27}$ The court demanded that the plaintiffs show "a reasonable basis for assuming jurisdiction"128 before permitting them discovery; the court also insisted that any discovery be limited. ${ }^{129}$ The D.C. Circuit stated simply that "a district court ... must proceed with circumspection, lest the evaluation of the immunity itself encroach unduly on the benefits the immunity was to ensure."130

In contrast, the D.C. district court has established relatively sophisticated standards. In Millicom International Cellular, SA v Republic of Costa Rica, ${ }^{131}$ the court explained that "[i]f plaintiffs set forth non-conclusory allegations that, if supplemented with additional evidence, would materially affect the court's analysis vis-a-vis the FSIA, then the court should permit limited discovery." ${ }^{132}$ In Millicom, the court permitted the plaintiff to conduct discovery regarding the nature of the defendant's commercial relationship with the United States, explaining that "[t]hese representations, the nature of which can only be determined through discovery, may well decide the question of whether the defendant['s] actions . . . creat[ed] a direct effect on the United States." ${ }^{133}$ Conversely, in Crist $v$ Republic of Turkey, ${ }^{134}$ the district court applied the Millicom test and denied discovery where the plaintiff's allegations constituted nothing more than "conjecture and surmise"135 and where the plaintiffs failed to allege any specific facts supporting their theory of jurisdiction. ${ }^{136}$

\footnotetext{
${ }^{17}$ Rafidain Bank, 150 F3d at 176, quoting Arriba, 962 F2d at 534.

${ }^{128}$ Rafidain Bank, $150 \mathrm{~F} 3 \mathrm{~d}$ at 176, quoting Filus $v$ Lot Polish Airlines, 907 F2d 1328, 1332 (2d Cir 1990).

${ }^{120}$ Rafidain Bank, 150 F3d at 176.

${ }^{130}$ Papandreou, 139 F3d at 253.

131997 US Dist LEXIS 12622 (D DC).

${ }^{152}$ Id at *4 (The plaintiffs, cellular telephone system operators, alleged that the Republic of Costa Rica and its instrumentalities prevented them from competing in the local cellular services market and the defendants moved to dismiss on several grounds, including that they were foreign sovereigns under the FSIA.). See also Crist, 995 F Supp at 12, citing Millicom.

1997 US Dist LEXIS 12622 at *24.

${ }^{134} 995$ F Supp 5 (D DC 1998).

${ }^{235}$ Id at 13.

${ }^{136} \mathrm{Id}$.
} 
Although courts have articulated nominally different standards for permitting jurisdictional discovery under the FSIA, it is unclear whether the tests differ functionally. For example, while the Arriba test calls for "allegations of specific facts crucial to an immunity determination" ${ }^{137}$ and the Millicom test calls for "nonconclusory allegations" that discovery would "materially affect" the court's FSIA analysis, ${ }^{138}$ it is unlikely that the Arriba court would permit discovery where it would not "materially affect" the court's FSIA analysis. Indeed, courts frequently purport to use a combination of the tests without recognizing any functional differences between them. ${ }^{139}$ As one court has noted, "no bright-line standard exists" for either plaintiffs seeking discovery or defendants seeking to avoid it. ${ }^{140}$

Although the heightened pleading standards provide greater protection than the traditional approach, they still fail to protect adequately foreign sovereign immunity. Judicial application of these tests remains largely unpredictable. For example, Arriba's requirement of "allegations of specific facts"141 provides little indication of when a plaintiff's allegations are sufficient to trigger discovery. Many questions remain for litigants: Are allegations of specific facts sufficient when those facts would tend to prove the existence of jurisdiction? Is a plaintiff entitled to discovery when those allegations materially affect the analysis? Or must a court deny discovery where a plaintiff has alleged specific facts that are necessary but insufficient to prove jurisdiction? Arriba and its progeny leave the answers unclear.

When courts employ balancing tests, even greater confusion results. ${ }^{142}$ Balancing tests rely on ad hoc determinations of the intrusiveness of discovery and considerations of equity; therefore, they fail to provide parties with predictable standards for when discovery will be permitted. Indeed, some academics have suggested that balancing tests are predictable only in their tendency to "balance" in favor of jurisdiction. ${ }^{143}$ As one court explained,

\footnotetext{
${ }^{15}$ Arriba, 962 F2d at 534.

${ }^{158}$ Millicom, 1997 US Dist LEXIS 12622 at *4.

${ }^{130}$ See, for example, Crist, 995 F Supp at 12 (citing all three tests as a basis for its conclusion).

${ }^{140} \mathrm{Id}$.

${ }^{141} 962$ F2d at 534.

${ }^{142}$ See, for example, Rafidain Bank, $150 \mathrm{~F} 3 \mathrm{~d}$ at 176 (noting a "delicate balanc[e]" between the need for discovery and perfection of immunity).

${ }^{13}$ See Kurt Riechenberg, The Recognition of Foreign Privileges in United States Discovery Proceedings, $9 \mathrm{Nw}$ J Intl L \& Bus 80, 126 (1988) ("The balancing of interests is nothing but the assertion of the primacy of United States interest in the guise of applying an international jurisdictional rule of reason."), citing Harold G. Maier, Interest Balancing and Extraterritorial Jurisdiction, 31 Am J Comp L 579, 581-82, 588-95 (1983).
} 
"courts inherently find it difficult neutrally to balance competing foreign interests. When there is any doubt, national interests will tend to be favored over foreign interests. ${ }^{p 44}$

These tests frustrate the purposes of the FSIA and the general policies underlying foreign sovereign immunity. First, the unpredictability of judicial discovery standards is plainly inconsistent with Congress's intent to create "firm standards" as to when a foreign state will be immune from the burdens of litigation. ${ }^{145}$ As the Supreme Court has explained, "predictability [is] essential to any international business transaction." 146 Unpredictable discovery standards make it more difficult for U.S. corporations to assess the costs of dealing with foreign entities and decrease the willingness of foreign governments to deal with U.S. corporations. ${ }^{147}$

Second, even the more predictable tests, such as the one espoused in Millicom, ${ }^{148}$ fail to give foreign sovereigns adequate protection from intrusive discovery. Because courts have not required plaintiffs to possess actual admissible evidence to demonstrate jurisdiction, plaintiffs are permitted to allege first and prove second. Often a plaintiff-with no evidentiary basis-may be able to allege specific facts to demonstrate that discovery might uncover evidence that will materially affect the court's jurisdictional analysis. For example, in Gabay, the court permitted limited discovery where the plaintiff's allegations and supporting documents did not constitute evidence admissible at trial and were "legally insufficient" to defeat immunity simply because the allegations suggested that "admissible evidence might well be obtained if discovery were permitted." 149 As a result, plaintiffs often may be able to engage in the sort of broad-ranging "fishing expeditions" that FSIA immunity was designed to prevent. ${ }^{150}$

\footnotetext{
${ }^{14}$ Laker Airways Ltd v Sabena, Belgian World Airlines, 731 F2d 909, 951 (DC Cir 1984).

${ }^{145} \mathrm{HR}$ Rep No 94-1487 at 7, reprinted in 1976 USCCAN at 6604 (cited in note 10).

${ }^{14}$ Scherk $v$ Alberto-Culver Co, 417 US 506, 516 (1974) (discussing predictability in the context of international arbitration awards).

${ }^{107}$ Unpredictable discovery standards raise the transaction costs for both the U.S. corporation, which must weigh the risk that it will be unable to seek judicial relief, and the foreign entity, which must weigh the risk that it will be forced to comply with costly and burdensome discovery. See Richard A. Posner, Economic Analysis of Law 543 (Little, Brown 4th ed 1992) (noting that unpredictable rules lead to suboptimal levels of activity because they raise the risk that permissible activities will be punished and decrease the certainty that impermissible activities will be punished).

${ }^{34}$ See text accompanying note 132.

160151 FRD at 257.

${ }^{130}$ See note 64 and accompanying text.
} 
Furthermore, these tests permit plaintiffs to reach discovery even where discovery is unlikely to produce evidence sufficient to prove jurisdiction. For example, the Millicom test permits plaintiffs to reach discovery upon a mere showing that discovery will "materially affect" the court's analysis;, ${ }^{151}$ Arriba permits discovery where it is "crucial to an immunity determination;" "152 and Gabay permits discovery where "admissible evidence might well be obtained."153 Applying these standards, district courts have frequently permitted discovery only to hold years later that they never possessed a statutory basis for asserting jurisdiction over the foreign sovereign. ${ }^{154}$ Accordingly, under the heightened pleading tests, foreign sovereigns will be subjected to discovery whenever the evidence sought by the plaintiff simply buttresses his jurisdictional claim - even if that evidence is insufficient to prove an exception to immunity by a preponderance of the evidence. ${ }^{155}$

\section{AN ALtERNATIVE APPROACH}

Current approaches to jurisdictional discovery under the FSIA fail to adequately protect foreign sovereigns from the burdens of litigation in U.S. courts. What is needed is an approach that provides greater protection for foreign sovereigns and greater certainty for both U.S. and foreign actors.

Rather than permit plaintiffs to obtain discovery where they have merely advanced allegations that would buttress their claims, courts should permit limited jurisdictional discovery only where a plaintiff (1) has produced some admissible evidence of jurisdictional facts and (2) can show that there is a reasonable likelihood that discovery will produce evidence sufficient to prove jurisdiction by a preponderance of the evidence. Thus, unlike present formulations that simply require plaintiffs to prove that the evidence they seek is "essential" or "material," this test would require plaintiffs to prove that the materials they seek are sufficient to defeat a claim of sovereign immunity. Such an approach

1311997 US Dist LEXIS 12622 at *4.

152962 F2d at 534.

1531 FRD at 257.

${ }^{154}$ See, for example, Millicom International Cellular, SA v Republic of Costa Rica, 995 F Supp 14 (D DC 1998); Gabay v Mostazafan Foundation of Iran, 968 F Supp 895, 900 (S D NY 1997), affd per curiam, 152 F3d 918 (2d Cir 1998); Filus v Lot Polish Airlines, 939 F Supp 199 (E D NY 1996), affd per curiam, 133 F3d 169 (2d Cir 1997).

${ }^{155}$ Courts usually recognize that subject matter jurisdiction must be demonstrated by a preponderance of the evidence. See, for example, Stephens $v$ American Home Assurance Co, 811 F Supp 937, 959 (S D NY 1993) ("It is well established that the [plaintiff] has the burden of showing that the Court has jurisdiction by a preponderance of the evidence."). 
would increase the predictability of FSIA determinations and enhance the protections of sovereign immunity while still leaving the plaintiffs some "space for discovery."156

\section{A. The Reasonable Likelihood Test}

Where the costs of litigation are asymmetrical-either because society values the success of one party more highly than the other or because the burdens of litigation are unevenly divided-courts and Congress typically attempt to adjust the standard of proof accordingly. ${ }^{157}$ For example, courts have consistently required plaintiffs in corporate derivative suits ${ }^{158}$ and federal civil rights cases ${ }^{159}$ to state their claims with particularity before being permitted discovery.

In the context of foreign sovereign immunity, the costs of litigation argue heavily in favor of restricting plaintiffs' access to discovery. Discovery is likely to require defendants to submit to lengthy and expensive production of evidence, as well as impose political burdens on foreign actors. ${ }^{160}$ Plaintiffs, on the other hand, bear no similar litigation costs. ${ }^{161}$ Furthermore, while the United States has a strong interest in protecting its citizens and businesses in their dealings with foreign actors, ${ }^{162}$ it has an equally strong, if not stronger, interest in guaranteeing the sovereign immunity of foreign states. ${ }^{163}$ As discussed in Part II, permissive discovery rules threaten to impair America's political and economic relations with foreign states; discourage foreign entities from trading with American corporations and resolving their disputes within the United States' legal framework; and may encourage foreign governments to modify their own discovery and immunity laws in a manner hostile to U.S. political, economic, and military interests.

\footnotetext{
${ }^{138}$ Crawford-El v Britton, 93 F3d 813, 841 (DC Cir 1996) (Ginsburg concurring) (discussing the benefits of a similar rule in the context of qualified immunity cases), revd, 523 US 574 (1998).

${ }^{157}$ See Crawford-El, 93 F3d at 822 (plurality opinion) (describing asymmetrical costs and adjustments in the burden of proof in a variety of cases).

${ }^{158}$ See, for example, Joy $v$ North, 692 F2d 880, 889 (2d Cir 1982) (discussing early application of business judgment rule in response to claim of demand futility); Zitin $v$ Turley, 1991 US Dist LEXIS 10084, *5-10 (D Ariz) (same).

${ }^{155}$ See note 105 and accompanying text.

${ }^{100}$ See Part II.C.1.a.

${ }^{161}$ Plaintiffs, of course, might face additional costs if they are unable to litigate their claims.

${ }^{100}$ See HR Rep No 94-1487 at 1-9, reprinted in 1976 USCCAN at 6604-08 (cited in note 10) (arguing that U.S. citizens need greater access to courts in suits against foreign states).

${ }^{105}$ See Part II.C.1.
} 
In dealing with similar asymmetries in the context of qualified immunity, Judge Douglas Ginsburg has suggested that a plaintiff should be allowed to "pursue limited discovery only upon a showing that he has a reasonable likelihood of turming up evidence" that would meet his evidentiary burden. ${ }^{164}$ The U.S. Solicitor General has advocated a similar rule, with the added requirement that a plaintiff produce "some evidence" before being permitted discovery. ${ }^{165}$ The Solicitor General's proposed rule for qualified immunity can be applied in the sovereign immunity context, providing the optimal limitations on discovery against foreign sovereigns.

Although the Supreme Court apparently rejected these heightened discovery requirements in the context of qualified immunity in Crawford-El $v$ Britton, ${ }^{166}$ these standards provide a useful alternative to current limitations on discovery in the context of foreign sovereign immunity and pose none of the constitutional problems that led the Court to reject them in the qualified immunity context.

Most FSIA cases stand in sharp contrast to the typical federal civil rights suit. In contrast to the commercial nature of most FSIA suits, qualified immunity generally protects government officials from liability in suits arising from constitutional harm. ${ }^{167}$ In Crawford-El, the Supreme Court was driven by concerns about the importance of civil rights suits and the lack of alternative forms of redress for constitutional wrongs. ${ }^{168}$ For example, in Crawford-El the Court noted that there are few checks on the behavior of state government officials outside of Section 1983 suits. ${ }^{169}$

These concerns are largely absent in the FSIA context. In the realm of international commerce a number of extrajudicial factors

\footnotetext{
${ }^{104}$ Crawford-El, 93 F3d at 841 (Ginsburg concurring).

${ }^{10 s}$ Brief for the United States as Amicus Curiae in support of Respondent, Crawford-El $\checkmark$ Britton, 523 US 574 (1998), available at 1997 WL 606738, *26, citing Elliot v Thomas, 937 F2d 338, 345 (7th Cir 1991).

${ }^{16} 523$ US 574, 118 S Ct 1584, 1596-98 (1998). Although the Supreme Court did not explicitly reject Judge Ginsburg's discovery formulation, the Court's dicta strongly suggests that such an approach is impermissible in the context of qualified immunity.

${ }^{107}$ Qualified immunity protects government officials from suits alleging violations of constitutional or statutory rights. See Ross, ed, Sword \& Shield at 532 (cited in note 63).

${ }^{108} 118 \mathrm{~S} \mathrm{Ct}$ at 1593 ("In Harlow ... [w]e further emphasized: 'In situations of abuse of office, an action for damages may offer the only realistic avenue for vindication of constitutional guarantees."'), quoting Harlow v Fitzgerald, 457 US 800, 814 (1982).

${ }^{10}$ Crawford-El, $118 \mathrm{~S} \mathrm{Ct}$ at 1593 (describing Section 1983 lawsuits as "the only realistic' remedy for the violation of constitutional guarantees"). Compare this discussion with Judge Silberman's concurrence in Crawford-El, $93 \mathrm{F3d}$ at 836-37 (discussing the various statutory, reputational, and theological restraints on the actions of government officials).
} 
operate to constrain the behavior of foreign state actors. For example, foreign actors must worry about acting in a manner that will hurt their commercial reputation, expose them to liability in their own courts, or persuade the U.S. State Department or U.S. Trade Representative to take action against them. ${ }^{170}$ While the threats of diplomatic and economic pressure or reputational loss may not always be sufficient to constrain the behavior of foreign actors, the vast majority of FSIA plaintiffs possess far greater political and economic power than the run-of-the-mill Section 1983 plaintiff-prisoners. ${ }^{171}$ Accordingly, the need for judicial intervention is diminished in the context of FSIA suits. Moreover, the Supreme Court has suggested that courts must "exercise special vigilance" in protecting foreign actors from the burdens of discovery. ${ }^{172}$ Thus, it is unlikely that the Court will find that a plaintiff's right to conduct discovery against a foreign sovereign merits the same level of protection as a plaintiff's right to vindicate his civil rights against a domestic government official.

\section{B. The Reasonable Likelihood Test Adequately Protects Foreign Sovereign Defendants}

The reasonable likelihood test decreases the burden on foreign sovereign defendants in two ways. First, the requirement of "some evidence" forces plaintiffs to make a substantial threshold

\footnotetext{
${ }^{170}$ The U.S. Trade Representative ("USTR") frequently intervenes on behalf of U.S. corporations engaged in international commercial disputes. See, for example, US Farmers Vent Fury at Finnish Barley Shipment, European Rep (May 30, 1998) (USTR subsidizing American barley exports in response to Finnish corporation's exports to the United States of subsidized barley); Ruth Walker, Canada's Dry on Exporting Water, Christian Sci Mon 6 (June 15, 1998) (USTR intervening in dispute between U.S. entrepreneur and Canadian government regarding bulk water exports); Errol Oh, Chipping Away at Piracy, Malaysian Bus 20, 1998 WL 9225595 (June 1, 1998) (USTR involvement in overseas software piracy on behalf of US corporations). The State Department also frequently intervenes in commercial litigation. See, for example, In re Papandreou, 139 F3d 247, 252 (DC Cir 1998) (State Department intervening to assert an interest in the "senstive diplomatic considerations involved"); David Usborne, Swiss Banks Furious at U.S. Boycott Threats, The Independent 17 (July 3, 1998) (State Department intervening to resolve California and New York boycott of Swiss banks over unreturned Nazi gold). Furthermore, the State Department frequently intervenes to resolve matters relevant to the recently enacted extrajudicial killings and torture provisions of the FSIA. See, for example, David Scheffer, Human Rights and International Justice, US Dept State Dispatch 25, 1998 WL 12885578 (Nov 1, 1998) (discussing use of diplomatic pressure against alleged war criminals).

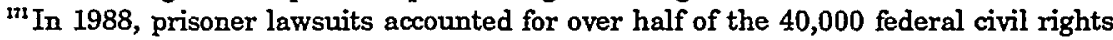
actions filed against government officials. See Crawford-El, 93 F3d at 830 (Silberman concurring). In 1993, prisoners alone filed 39,933 civil rights petitions. See Jody L. Sturtz, $A$ Prisoner's Privilege to File in Forma Pauperis Proceedings: May It Be Numerically Restricted, 1995 Det Coll L L Rev 1349, 1371 n 172.

${ }^{\mathrm{t} 2}$ Société Nationale Industrielle Aérospatiale v United States District Court for the Southern District of Iowa, 482 US 522, 546 (1987).
} 
showing of jurisdictional facts. Plaintiffs need not produce evidence that by itself would support a finding of jurisdiction, but they must demonstrate that some such evidence exists. This requirement prevents plaintiffs from simply alleging in detail facts that they only guess to be true. Plaintiffs must "have a concrete basis for believing that discovery will uncover the necessary evidence. ${ }^{173}$

For example, both Arriba and Millicom would permit discovery based on a hypothetical complaint alleging that the Central Bank of the Islamic Republic of Iran was at all times engaged in commercial activity in the U.S. through its alter-ego, "The Money Store." Specifically, Iran's Ministry of Finance engaged in daily teleconferences with The Money Store's corporate leadership and directed their corporate activity. The proposed test, however, would deny discovery unless the plaintiff could produce some admissible evidence of the alleged alter-ego relationship, such as phone logs or affidavits from disgruntled Money Store employees. Thus, the rule precludes plaintiffs from engaging in (even limited) fishing expeditions unless they have some evidence of a basis for jurisdiction. ${ }^{174}$

Second, courts can further protect foreign sovereigns by insisting that plaintiffs demonstrate a reasonable likelihood that discovery will uncover evidence sufficient to prove jurisdiction by a preponderance of the evidence. Unlike current formulations, the reasonable likelihood test requires plaintiffs to do more than just demonstrate that discovery will buttress their claims: it requires them to show that such discovery will be sufficient to uphold a finding of jurisdiction. Thus, the rule precludes even productive discovery where the evidence likely to be discovered cannot prove jurisdiction beyond a preponderance of the evidence.

Some have questioned the ability of lower court judges to apply uniformly a rule that depends so heavily on ex ante calculations of litigation success. Judge Silberman of the D.C. Circuit criticized the reasonable likelihood test in the context of qualified immunity claims, arguing that district courts would be unable to apply an ex ante test consistently, undermining the predictability of the law and inducing "more paralysis than discouragement of wicked actions. ${ }^{\$ 75}$ Such criticism underestimates the ability of

\footnotetext{
${ }^{175}$ Brief for the United States, 1997 WL 606738 at *27 (cited in note 165).

${ }^{17}$ The Supreme Court has upheld a similar rule in the context of selective prosecution claims. See United States v Armstrong, 517 US 456, 468-69 (1996). In Armstrong, the Court concluded that the public's interest in protecting prosecutors from burdensome discovery justified such a heightened standard. Id.

${ }^{175}$ Crawford-El, 93 F3d at 834 (Silberman concurring).
} 
lower courts to make ex ante determinations of litigation outcomes. In contrast to the judiciary's inherent difficulties in balancing foreign interests, ${ }^{176}$ U.S. courts are well-suited to determine the likelihood of success on the merits.

District court judges presently make similar ex ante determinations in a wide variety of contexts. When a district court rules on a motion for a preliminary injunction, it must determine whether the party seeking the injunction is likely to succeed on the merits. ${ }^{177}$ Courts conduct the same inquiry when determining whether to designate counsel to represent an indigent plaintiff in civil rights litigation. ${ }^{178}$ Similarly, in determining whether to permit discovery in shareholder derivative suits, courts are forced to evaluate the merits of the plaintiff's substantive claims at an early stage of litigation. ${ }^{179}$ The last example is most analogous to foreign sovereign immunity, since failure to get discovery in a derivative suit would, in most cases, end the litigation entirely.

Any forward-looking test will invariably result in some uncertainty. Nevertheless, a test that permits judges to determine the likely efficacy of discovery provides greater certainty than the traditional approaches, which permit unfettered discretion; or balancing approaches, which force courts to act beyond their institutional competence. Courts are institutionally well-suited to making predictions about litigation success and litigants are accustomed to making such predictions; because both courts and litigants are well-versed in such predictions, uncertainty is minimized. Neither courts nor litigants, however, are institutionally adept at balancing the competing interests of foreign sovereign immunity against the need to assert jurisdiction. And, much like the situation posed by pre-FSIA State Department determinations of immunity, "considerable uncertainty results." 180

In addition, present formulations, which simply require "allegations of specific facts" or allegations that will "materially affect" the analysis, engender similar uncertainties. Litigants can-

\footnotetext{
${ }^{178}$ See Part III.B.

${ }^{17}$ See, for example, Benten v Kessler, 505 US 1084, 1085 (1992) (per curiam) (rejecting preliminary injunction for failure to demonstrate "a substantial likelihood of success on the merits"); Hoover v Morales, 1998 US App LEXIS 32611, *3 (5th Cir) (same); Associated General Contractors of America v Metropolitan Water District of Southern California, 159 F3d 1178, 1180-81 (9th Cir 1998) (rejecting preliminary injunction for failure to demonstrate likelihood of success on the merits).

${ }^{178}$ See, for example, Wilborm v Escalderon, 789 F2d 1328, 1331 (9th Cir 1986) (stating that in forma pauperis is an extraordinary remedy that requires an evaluation of the "likelihood of success on the merits").

${ }^{179}$ See cases cited in note 158 .

${ }^{100} \mathrm{HR}$ Rep No 94-1487 at 9, reprinted in 1976 USCCAN at 6607 (cited in note 10).
} 
not accurately predict the likelihood that a discovery request will succeed or fail where success hinges simply on a vague judicial determination that the request is material. As discussed in Part III.B, these formulations leave a number of questions unanswered for litigants. In contrast, the proposed formulation would permit district courts to utilize their institutional competence and simply predict whether the evidence sought will be sufficient to defeat defendants' claims of immunity.

\section{The Reasonable Likelihood Test Permits Plaintiffs Adequate Jurisdictional Discovery}

Although the reasonable likelihood test makes it more difficult for plaintiffs to reach discovery, it still provides sufficient room for meritorious claims. Though the plaintiffs must present some evidence of jurisdiction, that evidence need not be sufficient to prove jurisdiction by itself. In the typical FSIA case involving a commercial activities exception to immunity, the plaintiff is likely to possess some evidence that the defendant engaged in commercial activities in the United States. For example, the prototypical commercial activities exception cases involve contract disputes; ${ }^{181}$ in these cases, plaintiffs will presumably possess some evidence demonstrating a commercial relationship. Moreover, plaintiffs will frequently be able to offer their own affidavits as evidence of the defendants' commercial activities or tortious acts. ${ }^{182}$ Where plaintiffs can demonstrate that discovery is likely to be not only fruitful but also persuasive, this rule will not preclude discovery. True, sometimes plaintiffs will be denied discovery and will consequently be unable to sustain jurisdiction, but these are the costs of immunity.

\section{CONCLUSION}

Judicial treatment of jurisdictional discovery under the FSIA has been inconsistent. While courts have articulated a number of different standards for limiting such discovery, current efforts uniformly fail to accord proper respect to the sovereignty of foreign states. This failure threatens to undermine international

\footnotetext{
${ }^{161}$ See Texas Trading \& Milling Corp Federal Republic of Nigeria, 647 F2d 300, 307-10 (2d Cir 1981) (discussing FSIA's treatment of contract as prototype of "commercial activity").

${ }^{102}$ Outside of the alter-ego context, plaintiffs will often be able to testify personally. For example, in Greenpeace, $946 \mathrm{~F}$ Supp at 786-87, plaintiffs were able to attest personally to the tortious acts but were simply unable to attest to the alter-ego relationship. Ultimately, however, proving alter-ego liability is likely to be difficult under any standard.
} 
comity. International comity enhances foreign states' willingness to transact with U.S. corporations, secures similar protections for the U.S. government, and generates greater acceptance of U.S. discovery practices. Courts should attempt to define more clearly the limits of jurisdictional discovery and to strike a balance between foreign sovereign immunity and the interests of plaintiffs in adjudicating claims. In place of current limitations, courts should predicate discovery upon a showing that the plaintiff is reasonably likely to prove jurisdiction beyond a preponderance of the evidence and should accordingly require plaintiffs to present some admissible evidence of jurisdiction prior to discovery. This approach better protects foreign sovereigns from unwarranted discovery and accords more closely with international notions of comity, yet still affords plaintiffs adequate opportunity to pursue legitimate discovery. 


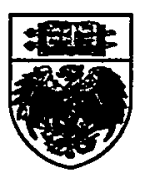

